\title{
UC-NRLF
}




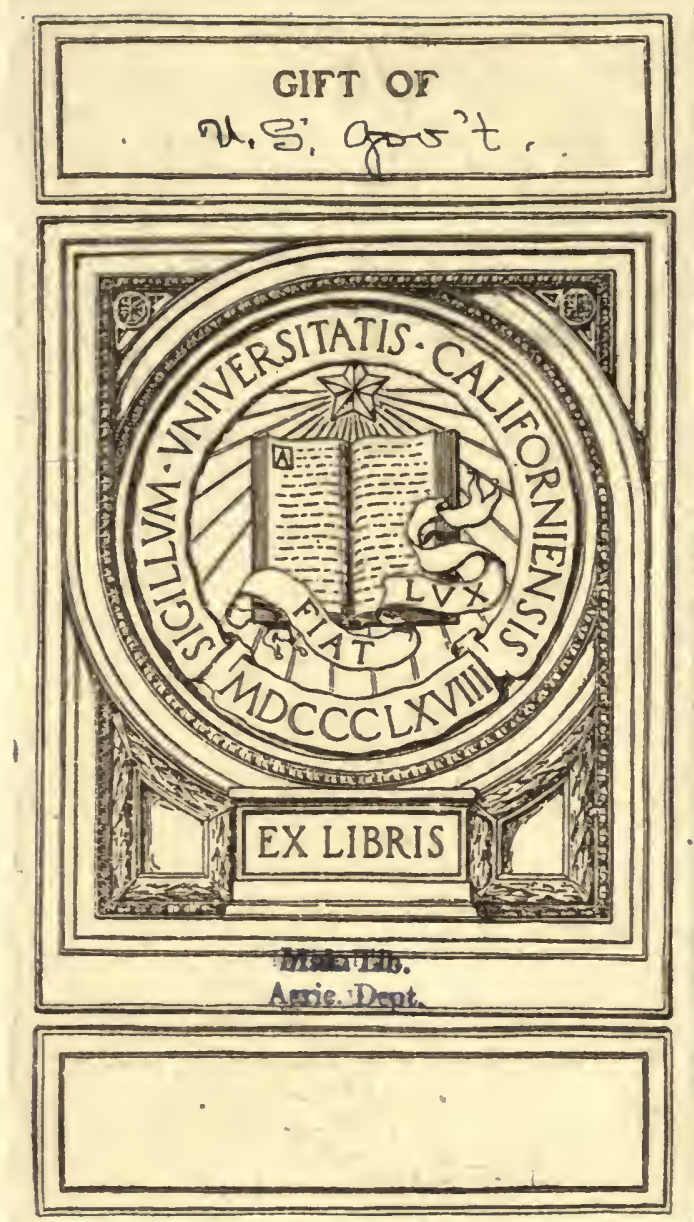


. 


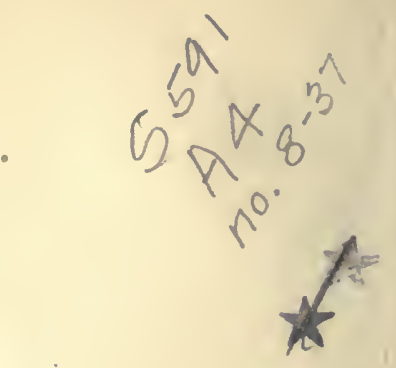

Main Lib.

Agric. Dept. 
U. S. DEPARTMENT OF AGRICULTURE, BUREAU OF SOILS-CIRCULAR No. 29. MILTON WHITNEY, Chief of Bureau.

SOLS OF THE EASTERN UNITED STATES AND THEIR LSE-VII.

\section{THE HAGERST'OWN LOAM.}

BY

JAY A. BONSTEEL,

Scientist in Soil Survey.

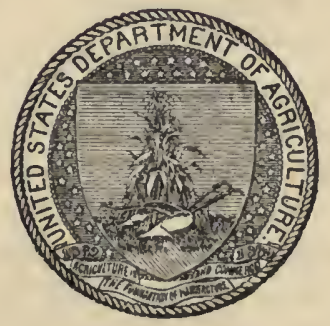

WASHINGTON:

GOVERNMENT PRINTING OFFIOE.

1911. 


\section{BUREAU OF SOILS.}

\section{Milton Whitney, Chief of Bureau.}

Albert G. Rice, Chief Clerk.

SCIENTIFIC STAFF.

Frank K. Cameron, in charge of Physical and Chemical Investigations. Curtis F. Marbut, in charge of Soil Survey.

Oswatd Schreiner, in charge of Fertility Investigations.

W J MCGEE, in charge of Soil Water Investigations. 


\section{SOILS OF THE EASTERN UNITED STATES AND THEIR USE $\leftarrow$ VII.}

\section{THE HAGERSTOWI LOAM.}

\section{GEOGRAPHICAL DISTRIBUTION.}

The Hagerstown loam is the most extensive of the valley limestone soils. It has been encountered in 24 different soil survey areas located in five different States, and in these areas 1,211,911 acres have been mapped. The Hagerstown loam is a residual soil derived through the partial solution of the massive blue limestones forming the floor of the Great Valley, which extends from eastern Pennsylvania across central Maryland and through western Virginia into Tennessee, Kentucky, and northern Alabama. In addition to this valley, which has been called the Cumberland Valley in Pennsylvania, the Hagerstown Valley in Maryland, and the Shenandoah Valley in Virginia, there are numerous smaller valleys included within the Appalachian system, which also have this limestone for their floor, and which are, therefore, occupied by the soils of the Hagerstown series. The Hagerstown loam is found in practically all of these main and minor valleys and it is remarkably uniform in its characteristics throughout its extent.

In addition to these typical valley areas the same soil is found covering a large proportion of the Bluegrass Region of Kentucky and in the Basin Region of central and southern Tennessee. In fact, the massive blue and usually pure limestones of these localities normally give rise to the soils of the Hagerstown series, and throughout the greater part of its extent the Hagerstown loam dominates the other types of the series.

As the soil survey work is extended additional important areas of this soil series and soil type will be encountered in Pennsylvania, Maryland, West Virginia, Virginia, Kentucky, Tennessee, and northern Alabama.

\section{CHARACTERISTICS OF SOIL AND SUBSOIL.}

The Hagerstown loam is characterized through practically its entire extent by a brown or yellowish-brown silty loam surface soil having a depth which ranges from 6 inches as a minimum to 12 or 14 inches in the deeper areas. This surface soil is soft and mellow and usually has the appearance of being well charged with organic matter. It grades 
downward into a yellow heavy loam or clay loam subsoil, which in turn grades into a heavier clay loam or clay subsoil at a depth of 2 feet to $2 \frac{1}{2}$ feet. This deeper subsoil is not infrequently of a brown or reddish color and in practically all cases it is sharply bounded by the underlying undissolved limestone rock. It is a general characteristic of the type, as with other soils derived from the harder limestones, that there is no gradation from subsoil into rock, but the subsoil material rests upon an uneven and corroded rock floor. This arises from the natural processes by which the soil is formed. It has been produced by the partial or complete solution of the calcium carbonate of the parent rock. The actual soil and subsoil material consists of the less soluble residues which have accumulated over the rock itself. There is thus no transition from rock to soil, as in case of soils derived from granite or sandstone, but a sharp boundary instead.

Only where thin layers of sandy rock exist, or where there has been an unusual amount of siliceous material in the limestone, are there to be found stony or rocky areas within the region occupied by the Hagerstown loam. The pure limestone which gives rise to the typical areas does not contain a sufficient amount of the less soluble materials to leave either stone or chert fragments in the soil or subsoil of this type.

It is not infrequently the case, even in the most typical areas of the Hagerstown loam, that uneven hardness in the rock or irregular solution, due to other causes, leaves ledges of the parent limestone which protrude through the soil covering. These limestone ledges exist even in the best fields in practically all the areas where the type lias been mapped. They are not entirely undesirable, since in many localities they furnish a supply of limestone to be burned in kilns upon the farm. The resulting stone lime is liberally applied to the soil in all of the more northern communities, where this practice prevails. These ledges also furnish building stone and material for the construction of highways and give a considerable revenue in those localities where they are thus utilized. The limestone ledges where they are unduly numerous are to be avoided, especially for the purposes of orchard planting, since the shallow covering of soil along their flanks does not maintain a sufficient amount of moisture to satisfy the needs of plants which are to occupy the ground for such a long period of time as do fruit trees.

The Hagerstown loam is easily distinguished from the majority of other soil types occurring within the same region. It is preeminently "the limestone soil" as distinguished from soils derived from other classes of rock. The surface soil is brown, friable, and soft and easily distinguished from the Hagerstown clay, which is much stifier and more tenacious. The soils of the Hagerstown series appear in various positions, but always at relatively lower elevations than the 
limestone soils of the Clarksville series, which are upland soils. The soils of the latter series are usually to be distinguished from those of the Hagerstown series by the gray color of the surface soil and by the presence of small or large quantities of chert and flint in both surface soil and subsoil.

\section{SURFACE FEATURES AND DRAINAGE.}

While the Hagerstown loam always occupies valley positions with respect to other upland soils, its surface is by no means level. In each particular area where it occurs, whether the soil be developed in belts several miles broad and many miles long, or as small narrow stretches, where the limestone still persists between bordering areas of more resistant rocks, it has been weathered away by the solution and removal of a large proportion of the calcium carbonate, or lime. Irregularities in the rate of this solution, due to differences in the permeability or the hardness of the parent rock and to other causes, have in all cases led to the development of a gently rolling to undulating surface valley floor, and low ridges and rounded hills are separated by minor valleys, small depressions, and the pitted, sink-hole topography which is characteristic of the regions underlain by pure limestones.

Owing to the fact that this soil type is distributed through a long major valley and through a multitude of smaller separate valleys, as well as to its geographical occurrence over a considerable range of territory, the absolute elevation of the surface of the type above sea level varies considerably. In general, however, the greater part of the area of the Hagerstown loam is found at an altitude ranging from about 250 feet to approximately 1,000 feet above sea level. Certain separated valleys, however, are found at altitudes as high as 2,000 feet. The minor irregularities of elevation within the different areas of the type are usually included within a range of 200 feet, although this is sometimes exceeded, particularly in the more southern areas.

In addition to the major streams which flow through and across these limestone areas and furnish an adequate surface drainage to the type, there is also in many of the areas an intricate underground drainage through caverns in the limestone rock. The surface waters flow across the soil for short distances and sink through round and kettle-shaped depressions into the crevices and caves hollowed within the underlying limestone. In this manner the drainage is carried off by underground streams and rivers which reappear in many instances at distant points in the form of great "boiling springs." This underground drainage in addition to the surface drainage is characteristic of the areas covered by soils of limestone derivation and particularly of the soils of the Hagerstown series. 
It is only in the more southern areas where the precipitation occurs principally in the form of heavy rain storms and where the total annual precipitation approaches 50 inches that erosion is at all a serious problem in connection with the tillige of the Hagerstown loam. In general the slopes included within the areas of this soil type are rather gentle. The rain water finds a deep and mellow bed into which it may percolate and the existence of innumerable small crevices, sink holes, and caverns within the limestone affords sufficient outlet to atmospheric water so that the washing of the surface soil is not serious. It is only upon the steeper slopes in the regions of the heaviest precipitation that this difficulty is encountered. Even in such regions erosion is not so serious a matter as upon other soil types, since the Hagerstown loam is a natural grass land, and areas which are not continuously under cultivation tend rapidly to reclothe themselves with native grasses like the Kentucky bluegrass, forming a thick surface mat of vegetation and of roots which serve to prevent erosion.

\section{LIMITATIONS OF' USES.}

The Hagerstown loam is so well adapted to the production of the staple general farming crops that its use for such purposes has practically eliminated any attempt at its development for special purposes, unless the production of certain grades of tobacco and the growing of hemp in Kentucky might be so considered. The type is easily tilled; the soil and subsoil are retentive of moisture; and they are adequately drained in practically all cases. In nearly all areas where the Hagerstown loam has been encountered, a sufficient supply of organic matter has been maintained in the surface soil for all practical purposes of high-class agriculture. With the exception of a few limestone ledges already noted, there are few mechanical obstructions to the cultivation of this soil. These qualifications in the nature of the soil itself have rendered it one of the most fertile and most highly prized general farming soils to be found in the extreme eastern portion of the United States. In fact the high value of this soil for such purposes has given rise to the current saying that "a limestone soil is always a fertile soil." This is practically universally true so far as the soils of the Hagerstown series are concerned, and particularly with reference to the Hagerstown loam. It is not necessarily true of all limestone soils.

There are undoubtedly other uses than the production of corn, wheat, oats, grass, hemp, and tobacco to which the Hagerstown loam might be put, but so long as it equals or excels all other soils in the area in which it occurs in the production of these crops, there would be very little incentive to undertake the production of specialties. The only present tendency toward specialization is in the planting of 
apple orchards in certain localities, and it is probable that for certain varieties the Hagerstown loam constitutes one of the best soils for apple production to be found in the limestone valley regions. This phase of specialization will be discussed under the head of crop adaptations.

\section{IMPROVEMENT OF SOIL EFFIOIENCY.}

From what has already been said of the characteristics of the Hagerstown loam it will be apparent that in general the present efficiency of this soil may be rated very high. There are certain areas, however, particularly in the more southern regions where the type is found, in which the soil efficiency might be improved, chiefly by the application of those methods of tillage and soil treatment which are common to the greater proportion of the type.

There has been a tendency in northern Alabama and in southern Tennessee to plant too large an acreage of this soil continuously to cotton or to corn. If total crop production throughout a long period of years is to be considered, it would be better, even in these locations where cotton growing is climatically possible, to adopt a rotation in which cotton and corn should take their proper place as the hoed crops in the rotation, to be followed by cowpeas or a small grain, and such crops in turn to be followed by seeding down to grasses among which clover should have an important place. Such a change in the cropping system upon this soil type would tend to prevent soil erosion in the only locations where this is a serious problem upon the Hagerstown loam. It will also result in a decided increase in the yields of the money crops included in the rotation.

In general the Hagerstown loam is adequately and efficiently tilled. In some localities, however, the gradual increasing of the depth of plowing is to be recommended, until the brown loamy surface soil has been increased in depth to 8 or 10 inches. This modification of the surface soil characteristics is not difficult, provided a little care is taken to incorporate organic matter and to plow about 1 inch deeper each year that the soil is broken. This necessity only exists over a small proportion of the entire area of the type.

In general, the drainage of the Hagerstown loam is adequate in all areas where it occurs.

It is only upon the more sloping and rolling areas of the Hagerstown loam, in the more southern locations where rainfall is heavy, that protection from erosion is usually required. The very simple expedients of contour farming, with the establishment of the few terraces left in grass, will usually meet all the requirements for protection on this type. This is especially the case where a proper rotation, including two or three years in grass during a part of the rotation is practiced. The ease with which a clover seeding is secured and the particu- 
lar adaptation of the Hagerstown loam to the production of Kentucky bluegrass predispose the areas of this type toward a natural grass covering. This peculiarity every where tends to minimize the difficulties experienced with crosion.

In general there is a satisfactory amount of organic matter in the surface soils of the Hagerstown loam. Wherever this supply has been depleted by the long-continued cultivation of intertilled crops, the restoration of organic matter is easily possible through the production of cowpeas, of which the roots and stubble should be incorporated in the soil, or through the laying down of the soil to grass and the plowing in of the sod at the end of two or three years' time. Little difficulty is experienced in maintaining the organic supply of the surface soil where these practices are in vogue.

Although in certain regions the Hagerstown loam has been cultivated for a period of more than 150 years with practically no applications of any mineral fertilizers and without any diminution of crop yield, yet the application of organic manures and particularly of large quantities of burned stone lime have been general through the best tilled and most fertile localities where this type is found. In more recent years also the application of mineral fertilizers, particularly in connection with the growing of the small grain crops, has become more general. The fertilizers thus applied are usually complete commercial mixtures with a large content of phosphoric acid and only moderate percentages of potash and of nitrogen. Satisfactory increases in the yield of wheat from such applications are generally reported, whether the source of phosphoric acid has been the phosphate rock, bone meal, or other organic source.

One of the peculiarities of soil treatment upon the Hagerstown loam, particularly in the Pennsylvania and Maryland areas where it occurs, has been that of heavy applications of lime at least once in the five-year rotation commonly practiced upon this soil type. Although the Hagerstown loam is directly derived from limestone rock, the method of its derivation is such, through the solution of the lime carbonate, that the noncalcareous impurities in the rock constitute the greater part of the residue which remains to form the soil and subsoil. Thus, though the soils of the Hagerstown series, including the Hagerstown loam, are limestone soils, they are not necessarily calcareous soils. At the same time lime rock is present at little depth upon practically all farms where this soil occurs and upon the majority of such farms there are outcroppings and ledges of the rock. Even the early settlers in southeastern Pennsylvania soon learned to burn this rock lime in their own kilns, using timber cut upon the farm for firewood. The practice of using this burned stone lime upon the soils of the Hagerstown series began during the period of the Revolutionary War and has been conducted uninter- 
ruptedly since. Heavy applications; 40 to 50 bushels per acre, are not uncommon and even greater quantities are sometimes used. The application of the linie is generally made just before the seeding of the ground to wheat, and with the wheat crop the seeding to grass and clover is also made. The heavy yields of these crops upon properly limed areas of the Hagerstown loam fully justify the labor and expense of the application of the lime. -

Aside from the inherent characteristics of the soil itself which maintain good texture, good structure, and a favorable condition of organic matter content, it is probable that the frequent applications of large quantities of lime constitute one of the greatest factors in the maintenance of the high average yields of wheat and of hay secured from this type. The contrast between the yields reported from limed and unlimed areas of the type tend to establish this conclusion.

\section{IIMITATIONS UPON SPECIAL CROPS.}

The chief special crops produced upon Hagerstown loam are hemp in the Bluegrass Region of Kentucky, and the White Burley tobacco in the same district, together with cigar-filler tobacco in a very local= ized area in southeastern Pennsylvania. Aside from these crops; apples constitute practically the only other special crop produced upon this type. The reasons for these limitations have already been given. It is probable that inherited customs in farming have ruled to some degree, but climatic circumstances have chiefly limited the production of hemp and of tobacco to the regions mentioned. There is no reason why the White Burley tobacco should not be produced upon the Hagerstown loam to excellent advantage in the Basin Region of Tennessee or in the valley region of western Virginia. There is no reason why the cigar-filler tobacco such as is raised in Lancaster County, Pa., should not also be produced upon this type in the Pennsylvania counties west of the Susquehanna River, or even in the Hagerstown and Frederick Valleys of Maryland, but these crops are practically unknown outside of the restricted areas indicated. The local knowledge of the care of these crops and the local demand for them constitute the chief limitations upon the area of their produc* tion.

In apple orcharding the Hagerstown loam has been recognized as well suited to the production of certain varieties suited to low altitudes and rather warm temperate climates. In general only those locations within the Hagerstown loam which possess some altitude and particularly good air and water drainage have been selected for the location of apple orchards. Too frequently land of this type, which because of some local peculiarities was somewhat rough or was interrupted by ledges, has been chosen for the establishment of apple orchards. While these locations are not so desirable as others found $93119^{\circ}-$ Cir. $29-11-2$ 
within the type, they have constituted areas which the individual farmer was willing to set aside from his general farming operations in order to establish either his home orchard or a small planting upon a commercial scale. Thus appie orcharding within recent times has been decidedly of secondary importance in all areas occupied by the Hagerstown loam. This limitation of the type with regard to fruit culture is economic rather than inherent in the soil or in its climatic surroundings.

\section{EXTENT OF OCCUPATION.}

The Hagerstown loam was one of the first soils in the eastern United States to be cleared of its heavy timber growth and occupied for farm use. Pioneer agriculture in southeastern Pennsylvania had its beginning upon this soil type and upon associated soils in the same general region. By the beginning of the eighteenth century the superior productiveness of the soils of the Hagerstown series, including the Hagerstown loam, had been recognized and the land was eagerly sought for the establishment of farms. With the influx of the German population into southeastern Pennsylvania about 1740 there was an added demand for these lands, since these settlers soon learned to prize the limestone soils aboive all others in the region. As a result the limestone valleys of the southeastern counties of Pennsylvania were rapidly filled with careful, skillful, German farmers. No labor was too great in the clearing of the heavy hardwood growths from soils of this character, and even the earliest title deeds to land in the region carefully set aside the period of time when the waters of local streams might be used by adjoining landowners for the purposes of irrigation. No little engineering skill was shown in storing the water of the smaller streams and even in conducting such waters across low divides for the purposes of watering the meadows, upon which practically all grass was grown at that period. Some of these irrigation systems are still maintained practically upon their original lines, though many have now fallen into disuse. With the growth of population the descendants of these early German settlers frequently followed these valley lands to the south and southwest and became established in the Hagerstown and Frederick Valleys of Maryland and even in the Great Valley of Virginia. Wherever the limestone valleys led them these careful farmers pushed on. The same high estimation of these soils of the Hagerstown series, dominated by the Hagerstown loam, was rapidly acquired by settlers of other origin. Thus during the 200 years during which soils of this character have been known to American farming, the Hagerstown loam and its associated soils have been eagerly sought for complete occupation by the best farmers. As a result very little land of this character remains uncleared and untilled, and practically every available acre 
in all localities where this soil type is found has been brought under cultivation and is maintaining a high-class agriculture. So great has been the demand for lands of this character that in regions reasonably near market facilities the values frequently run to $\$ 250$ or $\$ 350$ an acre, solely for the purpose of producing general farm crops like corn, wheat, and grass. In other more remote regions and under somewhat less skillful management the soils range in value from $\$ 30$ or $\$ 40$ to $\$ 100$ an acre, but in all cases the Hagerstown loam and its associated limestone soils are the most valuable of any in the communities where it and other soils occur. For these reasons the extension of agriculture upon this type is scarcely possible, although the improvement of agricultural conditions is still attainable in many areas where the type is found. Such improvements will necessarily follow the lines already indicated by the most skillful farmers in the best tilled areas of this soil.

\section{CROP ADAPTATIONS.}

The Hagerstown loam is almost universally esteemed for the production of corn. For this crop it possesses even a higher rating than the Hagerstown clay. The acreage yields vary considerably, depending upon the care with which the land is prepared and upon the skill exercised in tending the crop. In southeastern Pennsylvania, in Maryland, and throughout the Valley of Virginia a yield of 40 bushels of shelled corn per acre upon the Hagerstown loam would be considered a low average yield, while many farmers, by exercising the greatest care under favorable climatic conditions, have been able to maintain average acreage yields of 75 to 80 bushels throughout a considerable period of time. Even in the more southern States, where the climatic surroundings are possibly less favorable, the standard average yields for the Hagerstown loam are about 25 bushels per acre, with not infrequent yields under better tillage systems of 50 and 60 bushels per acre. The friable, easily worked surface soil, the heavy, retentive subsoil, the excellent store of organic matter in the surface soil, and the ease of cultivation of the land, all tend to make the Hagerstown loam an ideal corn soil within the Eastern States.

In all latitudes where the Hagerstown loam is found it is esteemed as a wheat soil, but generally the Hagerstown clay has the reputation of producing slightly larger yields. In Maryland and Pennsylvania the wheat yields upon the Hagerstown loam vary between 20 bushels and 35 bushels per acre, with a general average of about 28 bushels. This is nearly double the average wheat yield for the United States taken as a whole. In Virginia, Kentucky, and Tennessee the wheat yields range from 15 to 25 bushels with a general average of approximately 20 bushels per acre. Even in Alabama, where wheat is 
raised only to a limited extent, yields upon the Hagerstown loam are reported at. 12 to 20 bushels per acre and the acreage devoted to this crop in the northern counties where the type occurs is being gradually extencled. Greater familiarity with the crop, resulting in greater skill in its management, will undoubtedly increase these yields if wheat culture is continued in that locality.

Upon the Hagerstown loam oats are raised extensively, but in all localities are considered subordinate in importance and are certainly subordinate in acreage to wheat. In fact, in the more northern States the production of oats upon the Hagerstown loam is probably decreasing annually since the yields are not sufficiently high to com? pensate for the greater value per bushel of the wheat crop and oats are thus at an economic disadvantage upon the Hagerstown loam: The yields in the more northern States range from 25 to 40 bushels per acre and in the more southern latitudes from 20 to 30 bushels per acre. These yields are no higher than may be secured for oats upon other soil types which are less valuable for corn and wheat production and the crop is thus being excluded from any extensive production upon the Hagerstown loam.

The Hagerstown loam is universally esteemed as a grass soil. It is the soil which underlies the great Bluegrass Region of Kentucky and the similar bluegrass region of the Basin Section of Tennessee. Kentucky bluegrass is also a native upon this soil type in the Great Valley of Virginia and northward into Pennsylvania. The widespread distribution of the Kentucky bluegrass upon the Hagerstown loam and its associated soils has given rise to the existence throughout the period of its cultivation of excellent pasturage facilities in many States. For the finishing of beef cattle probably no other natural pasture grass is so valuable. As a result, the utilization of bluegrass pasture upon this type for beef production has been common since the earliest days of its occupation for agricultural purposes. With the introduction of other tame grasses the production of timothy and of red clover soon became general upon the Hagerstown loam. These grasses furnish a larger yield for the cutting of hay, and thus the corn production upon the type and bluegrass pasturage already established were early supplemented by the growing of the mixed tame grasses.

Hay constitutes one of the crops extensively grown upon the Hagerstown loam and the yields are universally good. In Pennsylvania, Maryland, and Virginia, the yield of hay ranges from 1 to 2 tons with an average of about $1 \frac{1}{2}$ tons per acre. This is equaled in many places in Tennessee and in Kentucky, while in Alabama, commonly supposed to be south of the natural grass belt, the yields of hay in those areas where clover and timothy have been generally sown have ranged from 1 to $1 \frac{1}{2}$ tons per acre, an amount unusually high 
for this latitude. Thus the Hagerstown loam throughout its extent is an unusually valuable soil for the production of the bluegrass for pasturage purposes, and of timothy and clover for the cutting of hay. More recently alfalfa has been introduced as a forage crop in many widely scattered locations upon the Hagerstown loam. In general the introduction of this crop has been successful. Good stands may be secured in practically all areas where the combined depth of soil and subsoil exceeds 3 feet, unless there is some unusual obstruction to subsoil drainage. In all cases the liming of the soil and its careful inoculation before seeding to this crop are highly essential. The area annually planted to alfalfa should be greatly extended throughout the territory occupied by the Hagerstown loam. In fact, it is one of the best soils of the Eastern and Southeastern States for the production of this crop.

These constitute the basic staple crops most universally grown upon the Hagerstown loam.

In addition to these crops the cigar-filler tobacco is raised upon the Hagerstown loam, chiefly in Lancaster County, Pa. Under the careful farming of that county the acreage yields range from 1,500 pounds to 2,200 pounds, and tobacco constitutes a valuable accessory to the other crops produced upon the farm. Throughout the region occupied by the Hagerstown loam in the Bluegrass Region of Kentucky the White Burley tobacco for manufacturing and export purposes is widely grown. The yields of this tobacco range from 1,000 to 2,000 pounds per acre, with a general average lying somewhere between 1,200 and 1,500 pounds. In both instances the tobacco fields usually occupy only a part of the territory annually given to the production of hoed crops and commonly tobaceo displaces a part of the corn acreage which would normally be planted. It constitutes a valuable money crop in both of these localities.

Hemp is not raised to any extent upon the Hagerstown loam except in Kentucky. The yields average about 1,200 pounds of fiber per acre. It is reported that the acreage devoted to hemp is being decreased even in this section.

There are several accessory crops which, owing to climatic peculiarities or to local demand, are grown upon the Hagerstown loam. Thus in northern Alabama and in southern Tennessee the prevalence of cotton farming in near-by localities has led to the growing of this crop upon the Hagerstown loam. The soil occurs only near the northern limits of the climatic adaptation of cotton, and while the yields range from one-third to three-fourths bale an acre, it cannot be said that cotton growing has any strong foothold upon the Hagerstown loam. Similarly cowpeas are grown to a limited extent in this more southern region as a forage crop in connection with corn. In a few localities in Tennessee a small acreage of canta- 
loupes has recently been planted upon this soil type, but it is believed that certain of the soils of the Clarksville series will be found to be better suited for the extension of this crop. Strawberries have also been grown locally upon the Hagerstown loam. In a few localities in northern Alabama peanuts and tomatoes have been successfully grown upon the type. All of these crops may be considered as of subordinate importance if the total extent of the Hagerstown loam in the eastern United States is held in view, although each has considerable importance in the particular locality where it is grown.

Fruits.-In general the Hagerstown loam has been considered too valuable for the production of corn, wheat, grass, or tobacco to be devoted extensively to the production of any tree fruits. However, there has been a growing appreciation of the value of this soil for the production of certain types of apples. In southeastern Pennsylvania locations within the area of the Hagerstown loam which possess good air and water drainage and over which the surface soil has a depth of 12 to 18 inches have been selected for the planting of the York Imperial, the Stayman Winesap, and the Smokehouse apples. The two former are adapted to all properly drained areas of the type, while the Smokehouse is only well suited to production upon the deeper phase already mentioned. Farther south, in Maryland and in Virginia, there are some commercial orchards upon this type, and here orchards of the York Imperial, Ben Davis, Stayman Winesap, Yellow Transparent, and Grimes Golden have been planted. They bear rank in the order named in their degree of adaptation to production upon this type. The first three of these apples might well be grown at proper elevations upon the Hagerstown loam in the valleys of eastern Tennessee.

Peaches are not well suited to production upon the Hagerstown loam in any of its areas. By contrast they are well suited to the production upon other types commonly found in association with it, and the planting of peach orchards is not, therefore, to be recommended upon this type.

Because of the preeminent adaptation of the Hagerstown loam to the production of corn, wheat, and grass as standard crops and of tobacco and hemp as special crops, the agriculture of the regions dominated by this type has naturally gravitated into a certain standard crop rotation. In the more northern regions in Pennsylvania, Maryland, and the Valley of Virginia this standard rotation consists of one year of corn followed by either one or two years of wheat, which is succeeded by two years of grass production, when the rotation again returns to corn. This is one of the oldest standard rotations in the eastern United States, and it has undoubtedly been maintained without interruption upon some of the older farms in southeastern Pennsylvania since the middle of the eighteenth century. 
The production of hemp or tobacco in Kentucky has but slightly modified this rotation. In that locality cither tobacco or hemp occupies the acreage for the first year, or it may be divided between the two crops. These crops are followed in the second year by corn, then by wheat, and ultimately by two years to grass seeding. InTennessee the corn, wheat, and grass rotation is prevalent, while in northern Alabama either cotton and corn in alternation or cotton, corn, and wheat constitute the beginning of a rotation which will probably become standardized with that of the more northern locations as the grass-producing value of the soil comes to be appreciated. Thus the Hagerstown loam almost universally maintains the old standard rotation of corn, wheat, and grass which has been used for 200 years upon portions of this type. It still excels the majority of the soils of the United States in the production of each of these crops. In Kentucky the type has withstood 125 years of constant crop production with little fertilization, and the yields now reported from considerable areas do not differ from yields recorded in 1797 within the same areas. This may be attributed to the excellent inherent characteristics of the soil itself and to the persistent use of a rational crop rotation. Similarly in eastern Pennsylvania this soil constitutes the mainstay of as prosperous and perfect a general-farming system as can be found in the United States. Here, also, known records of crop yields establish the fact that these have been increased rather than decreased by two centuries of well-regulated farming. It would be difficult to demonstrate in any more conclusive way the fact of continued and even increased soil efficiency when the best farming methods are applied to the tillage of a naturally prodictive soil.

FARM EQUIPMENT.

The Hagerstown loam requires for its proper tillage, and easily supports by its crop production, the heavy farm teams which are required for the best general-farming purposes. While the surface soil is friable and easily tilled, its considerable depth requires the use of horses weighing from 1,300 to 1,500 pounds apiece, either in the double teams or in the 4-horse hitch which is common in Pennsylvania, Maryland, and Virginia. In this connection the heavier plows and tillage implements are also most economically used, in order to effect the deep plowing and thorough tillage required by the type. Corresponding with this portion of the equipment, the other farming tools and farm machinery are usually strong, well built, and ample in size for farm purposes. In some portions of the area occupied by the type it is unusual to see less than a 4-horse team used, even for the most simple purposes of the farm operations.

Long years of successful tillage of this land have generally given rise to such prosperity that the farm buildings upon the farms 
chiefly covered by the Hagerstown loam frequently have a value approximating that of the land itself. In southeastern Pennsylvania it is not uncommon to see two and three story barns which have cost from $\$ 6,000$ to $\$ 10,000$ for their construction, and substantial brick or stone houses which have been erected at half that price. Throughout the area where the Hagerstown loam is found, the prevalence of the type may easily be detected by the substantial farm buildings and the well-kept appearance of these and all other farm equipment. Generations of prosperous farming have rendered this possible.

The grass and grain farming which is prevalent upon the soil type have not only necessitated these larger buildings for the storage of the crops, but in many instances have also necessitated provision for the stabling and care both of the work stock and beef animals which are matured and fattened upon this produce. In addition, well-constructed tobacco barns are to be found wherever that crop is also grown. It is not infrequently the case, particularly in southeastern Pennsylvania, that the farmer will also maintain a lime kiln, which he has constructed for the purpose of burning the lime rock for use upon his own fields. Not every farm is thus provided, but in each community several kilns are likely to be found.

In this way the character of the soil, its natural crop adaptations, and the logical use of these crops have dominated the character of the equipment in teams, tools, and buildings found upon the farms occupied by the Hagerstown loam.

\section{SUMMARY.}

The Hagerstown loam is the most extensive and agriculturally the most important of the valley limestone soils.

It occurs from southeastern Pennsylvania through Maryland, the Great Valley of Virginia, and associated minor valleys of West Virginia and Tennessee, southward to the valley regions of northern Alabama. It also occupies a considerable area in the Bluegrass Region of Kentucky and in the Basin Region of central Tennessee.

It is a soil adapted to the production of the staple, general farm crops rather than to the growing of any unusual special crops.

It is chiefly suited to the production of corn, wheat, and grass, with oats as a minor small-grain crop.

It is a soil which on account of its high and well-sustained producing capacity has largely given rise to the reputation of limestone soils for fertility.

In certain localities it also constitutes an excellent soil for the production of the White Burley tobacco and of cigar-filler tobacco.

In Kentucky alone it is utilized for the production of hemp. 
Owing to climatic surroundings it is also used for the production of cotton and cowpeas in northern Alabama.

In general this type has been held at too high a value for general farming purposes to permit of its extensive use for orcharding, but in some portions of Pennsylvania, Maryland, and Virginia it has been planted to a restricted number of apple varieties.

The Hagerstown loam was early sought as a valuable general farming soil and has been completely occupied by productive and valuable farms.

Its crop producing capacity has been maintained and in many instances increased during 200 years of cultivation.

'The proper disposition of the corn and grass grown upon this type, together with the prevalence of native bluegrass pasture over it, led at an early date to the establishment of beef production as an important branch of farming on its area.

The Hagerstown loam easily holds high rank among the most fertile soils in the eastern portion of the United States.

Approved.

JAMES WiLson,

Secretary of Agriculture. 


\section{APPENDIX.}

The following table shows the extent of the Hagerstown lonm in the areas surveyed to this time.

In the first column is stated the particular soil survey in which the soil was encountered; in the second column, its extent of derelopment in acres; and in the third column, the volume of the Field Operations of the Bureau of Soils in which the report upon the area may be found. Those desiring a detailed description of the soil and of the general conditions which surround it in any particular area may consult these volumes in almost any public library.

Areas of the Hagcrstown loam encountered in the soit survey.

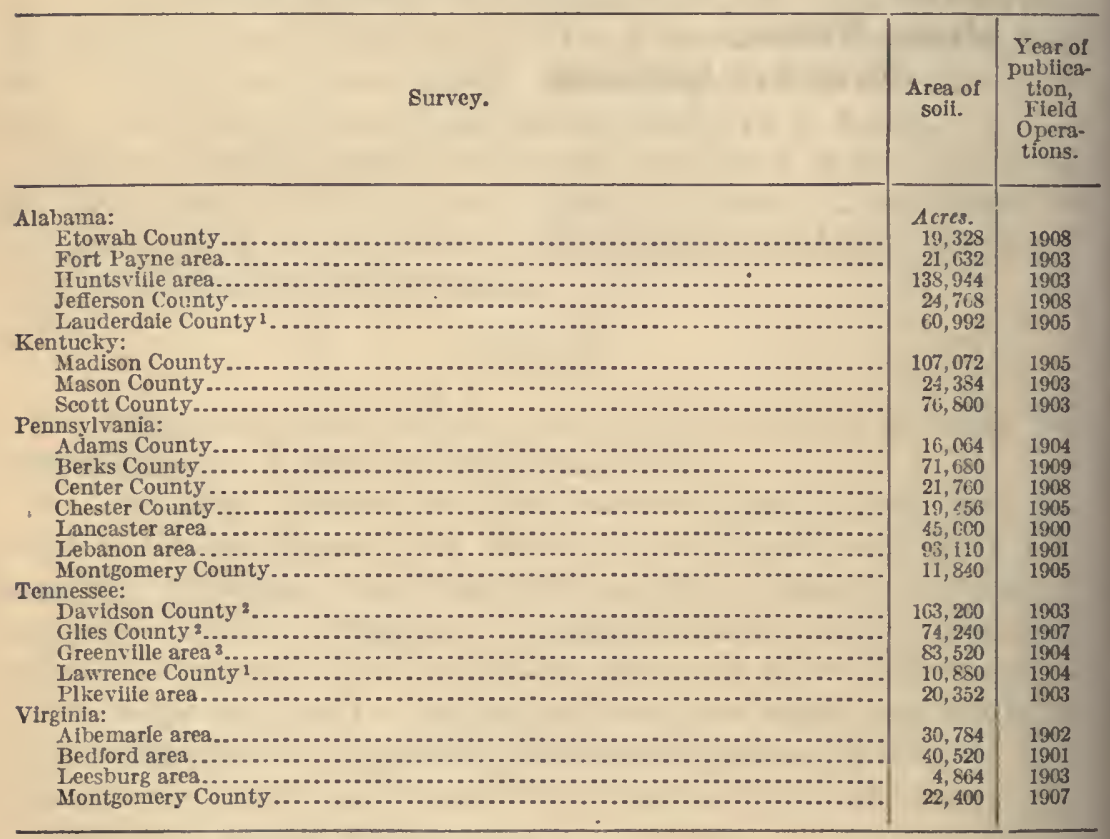

1 Mapped as Clarksrille clay loam.

Mapped, In part, as Davldson loam; In part, as Hagerstown loam. Mapped as Fort Payne loam. 

YC 67891

U. C. BERKELEY LIBRARIES

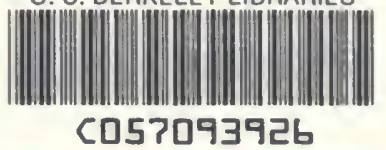

C057093926

P.

- $\therefore$

act.

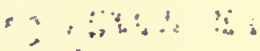


